\title{
$\mathrm{Ar}-\mathrm{H}_{2}$ アークプラズマ法による超微粒子の 生成速度に及ぼす電流および電圧の効果
}

\author{
斉 藤 勝 男
}

群馬大学工学部

J. Japan Inst. Metals, Vol. 60, No. 11 (1996), pp. 1125-1129

\section{Effect of Arc Current and Voltage on Production Rate of Ultrafine Particles by Ar- $\mathrm{H}_{2}$ Arc Plasma Method}

Katuo Saitou

Faculty of Engineering, Gunma University, Kiryu

\begin{abstract}
The arc current and voltage were taken as influence factors on the generation rate of ultrafine particles using an $\mathrm{Ar}-\mathrm{H}_{2}$ arc plasma method and the effect of these factors on the ultrafine particle generation rate was studied.

Two types of the electrode tip shape, that is, the vertex angle of $90^{\circ}$ and hemisphere, were used to investigate its shape effect on the generation rate.

Experiments were mainly carried out under Ar-50\% $\mathrm{H}_{2}$ mixed gas at atmospheric pressure, the arc generation condition of $25-40 \mathrm{~V}$ and $90-220 \mathrm{~A}$.

The generation rate of ultrafine particle under the condition of constant arc voltage gives the maximum value with respect to the arc current. The arc current which provides the maximum generation rate has the tendency that does not depend on the arc voltage when the electrode of acute shape is used.

The arc current dependence of the generation rate under constant arc voltage, three kinds of the voltage dependence were observed; the generation rate decreases monotonously, increases monotonously and have the minimum value with increasing arc voltage.

The arc current and voltage dependence of the generation rate is discussed from the view point of the magnitude of velocity of the plasma jet which generates from both the electrode and the anode heating by electrons.
\end{abstract} (Received May 31, 1996)

Keywords: nickel, ultrafine particle, arc plasma, plasma jet, electrode, generation rate

\section{I. 緒言}

超微粒子はバルク材料とは異なった性質を持つため新素材 開発における有用な材料として期待されている。超微粒子を 製造する方法は多くあるが，超微粒子の工業的使用を検討す る場合には多量生産可能な力法が必要である。この方法の一 つとして $\mathrm{Ar}-\mathrm{H}_{2}$ アークブラズマ法(1)(2) 挙げることができ る.この方法は原理的には水素存在下でのプラズマアークに よる金属の蒸発に基らいているためアーク発生条件が粒子生 成過程に大きな影響を及注すことは明らかである。しかし， 粒子生成過程に及隹す諸因子の影響，粒子生成機構について は末だ不明な点が多くある。

アーク発生に影響を与える因子以は幾つかあるが，著者は 諸因子の一つとして電極先端形状を取り上げ，超微粒子生成 速度に及活与角度効果について前報(3)で明らかにした，超微 粒子の工業的使用でのコストをも含む効率的多量生産のため には生成過程に影響を及添す諸因子の効果についてさらに調
査することが必要である，このため，本研究ではアーク発生 に最も直接的影響を及ぼす因子としてアーク電圧, 電流に注 目し，超微粒子生成速度に及ぼすそれらの效果火ついて検討 与ることを目的とした，その際，電極として先端形状が $90^{\circ}$ 扣よび半球状の 2 種類を用い, 超微粒子生成速度に及注す 角度效果汇ついて子検討した。

\section{II. 試料および実験方法}

試料には純度 $99.9 \%$ の $\mathrm{Ni}$ を用い，実験前に約 $4 \mathrm{cc}$ の大 さのボタン状とした。

実験装置には富士電波工機秼製のミクロナイザーを用い た.この装置の概略抏よび超微粒子作製方法は既報(3)で述べ たので略する。

超微粒子生成速度はアーク発生前後の試料の重量差をア一 ク発生時間で除した值としアア一ク発生時間は実験条件によ

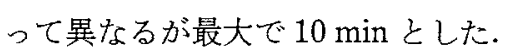

電極には直径 $4 \mathrm{~mm}$ の $-2 \% \mathrm{ThO}_{2}$ を用い，その先端角度 


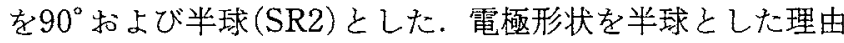
は長時間使用を考えた場合に形状が最も安定していると考克 たためである。電極先端はアーク発生時間の増加炕より損楊 する傾向接るが，本実験では先端の損傷は目視の限りでは 認められなかった。

アーク電王は 25〜 40 V，電流は 90〜220 A の範用で可変 とした．使用した搌合ガスは $\mathrm{Ar}-\mathrm{H}_{2}$ とし，水素濃度を $50 \%$ まで可変した。トーチガス流量は $15 \mathrm{~L} / \mathrm{min}$ ，ハースガス流 量は $20 \mathrm{~L} / \mathrm{min}$ とした。超微粒子生成速度に及活与電生括よ び電流の影響を調べる場合には $\mathrm{Ar}-50 \% \mathrm{H}_{2}$ 混合ガスのみを 使用した。

\section{III. 実 験 結 果}

\section{1. 超微粒子生成速度に及ばす水素濃度および電極形状の 効果}

アーク電压 $30 \mathrm{~V}$, 電流 $180 \mathrm{~A}$ の条件で電極先端形状が半 球の場合に淤方水素濃度と生成速度 $(R)$ との関係を Fig. 1 亿示寸，生成速度は水素濃度の增加ととる熷し，水素濃 度30〜40\%を境にしてその増加割合は急増する傾向にある。 水素漂度が50\%以上での実験を行っていないためそれ以上 での水素濃度で生成速度がぞのよらな傾向を示すか不明であ るが，以前の結果(3)を下にすると水素濃度50\%以上での生 成速度の増加割合は低くなると思われる。

Fig. 1 からで性成速度に及济す電極形状が半球の効果が 明らかでないため以前の結果(3) と併好て本実験結果を Fig. 2 火示す．図中で記号 HS は半球を意味する。图から明らか なように, 生成速度は水素濃度が $30 \%$ までは電極先端が尖 っていても丸及を帯びていてもその形状汇は依存しない，水

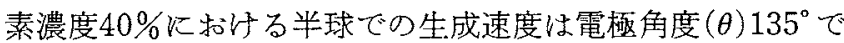

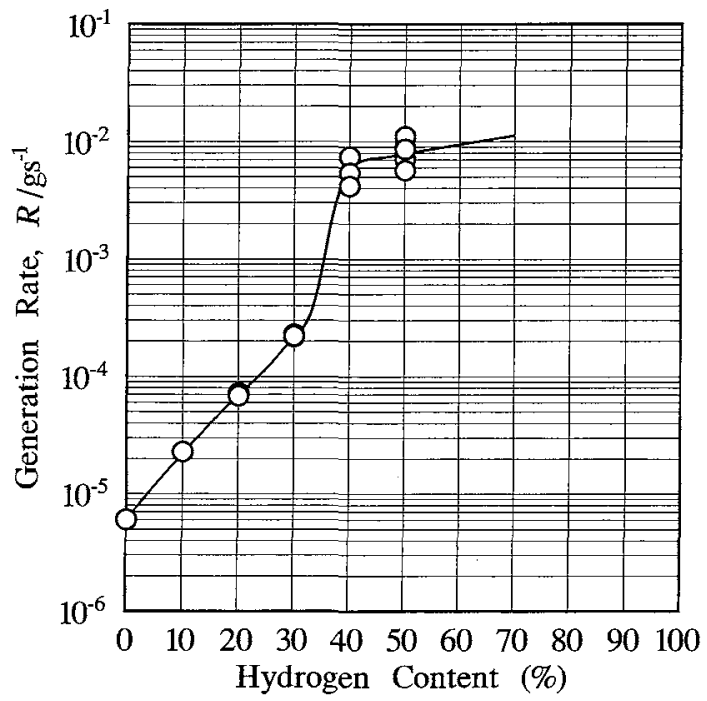

Fig. 1 Relation between hydrogen content and generation rate. Shape of electrode is hemisphere. Condition of arc generation is $30 \mathrm{~V}, 180 \mathrm{~A}$.

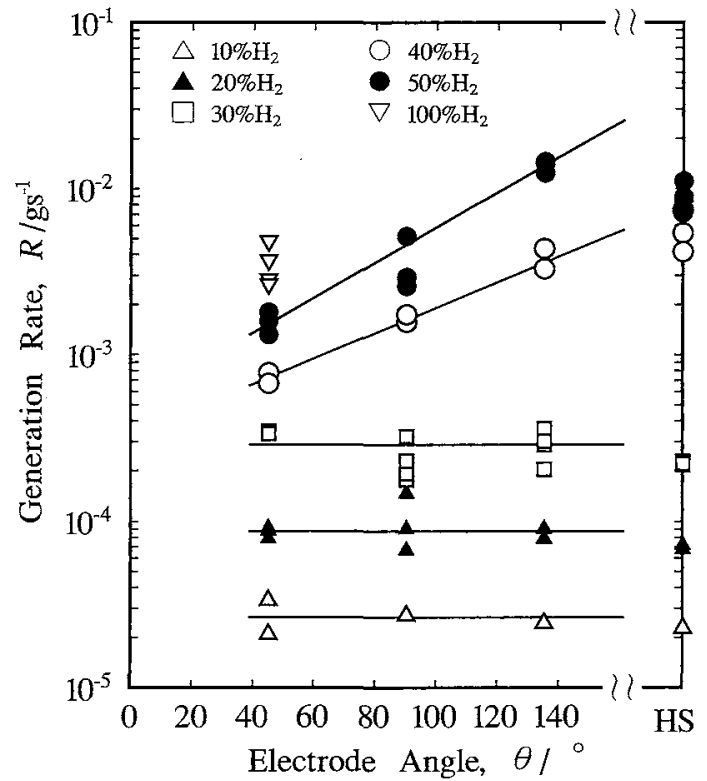

Fig. 2 Relation between electrode angle and generation rate. HS denotes electrode shape of hemisphere.

Arc generation condition is $30 \mathrm{~V}, 180 \mathrm{~A}$.

のと就と大差がないが，水素濃度50\%での生成速度は電極 角度 $135^{\circ}$ のそれよりる若干低い結果となっている。

\section{2. 生成速度に及ばすアーク電流の効果}

発生したアークプラズマの様相は種々の条件で変化する が，重要な一つの因子は電流である。このため，アーク電压 一定で電流 $(I)$ を变化させた場合に和ける超微粒子生成速度 の值を Fig. 3(a)，(b)に示与.

図より明らかなように生成速度はアーク電压の大小拘わ らず電流の増加とともに増し，最大値を経た後に減少する傾 向にある，岡田ら ${ }^{(4)}$ ，遠藤ら ${ }^{(5)}$ も同様な結果を得ているが， 本実験との相違恃彼らの結果が最大値を経た後に最小値を示 し再び増加傾向となる点である。

最大値を示す傾向は電極形状が異なっても同樣であるが, 電極角度 $90^{\circ}$ の場合の汪らが明瞭である. 生成速度の最大值 を与学る電流值はアーク電压依存しない上らに見受けら れ，その值は電極角度 $90^{\circ}$ で $120 \sim 130 \mathrm{~A}$, 半球では電圧 30 $\mathrm{V}$ 扎よび $35 \mathrm{~V}$ で $180 \mathrm{~A}$ とすることができる. 電極形状が半 球状で，電圧 $25 \mathrm{~V}$ 牤よび $40 \mathrm{~V}$ では電流增加付対して最大

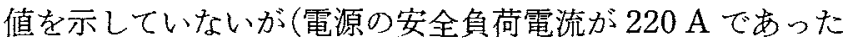
ためそれ以上の電流で測定していない)，さらに大電流で測 定すれば電圧 $30 \mathrm{~V}$ 拉よび $35 \mathrm{~V}$ での傾向と同様になると予 想される。

\section{3. 生成速度に及ぼすアーク電圧の効果}

アーク電圧 $(E)$ は極間間隔に低存する(粗い近似では比例 する $)^{(6)}$ ．したがって，電流一定の条件で電圧を変化させる ことはアークの長さを変化させることになるため生成速度に 影響を及活す。この結果を Fig. $4(\mathbf{a})\left(\theta=90^{\circ}\right)$, (b) (半球)に 

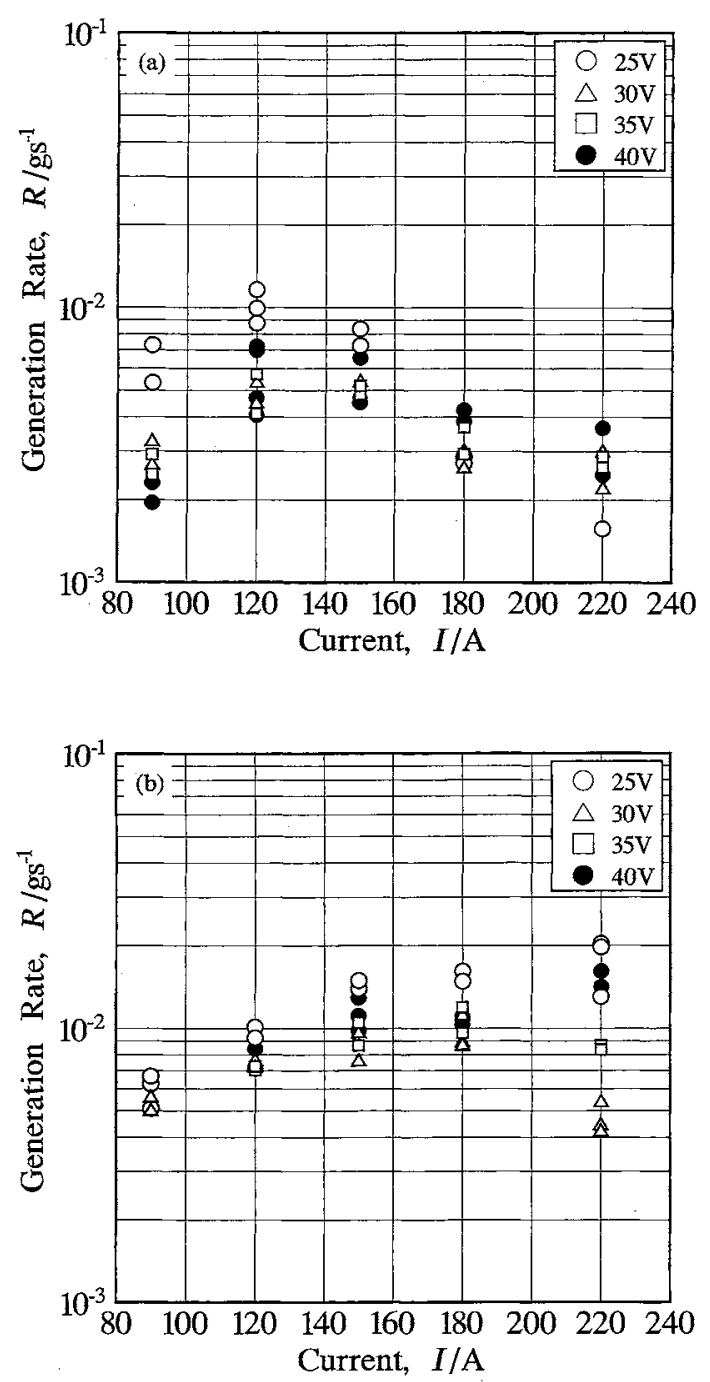

Fig. 3 Relation between arc current and generation rate. Hydrogen content is $50 \%$. (a) $\theta=90^{\circ}$, (b) hemisphere.
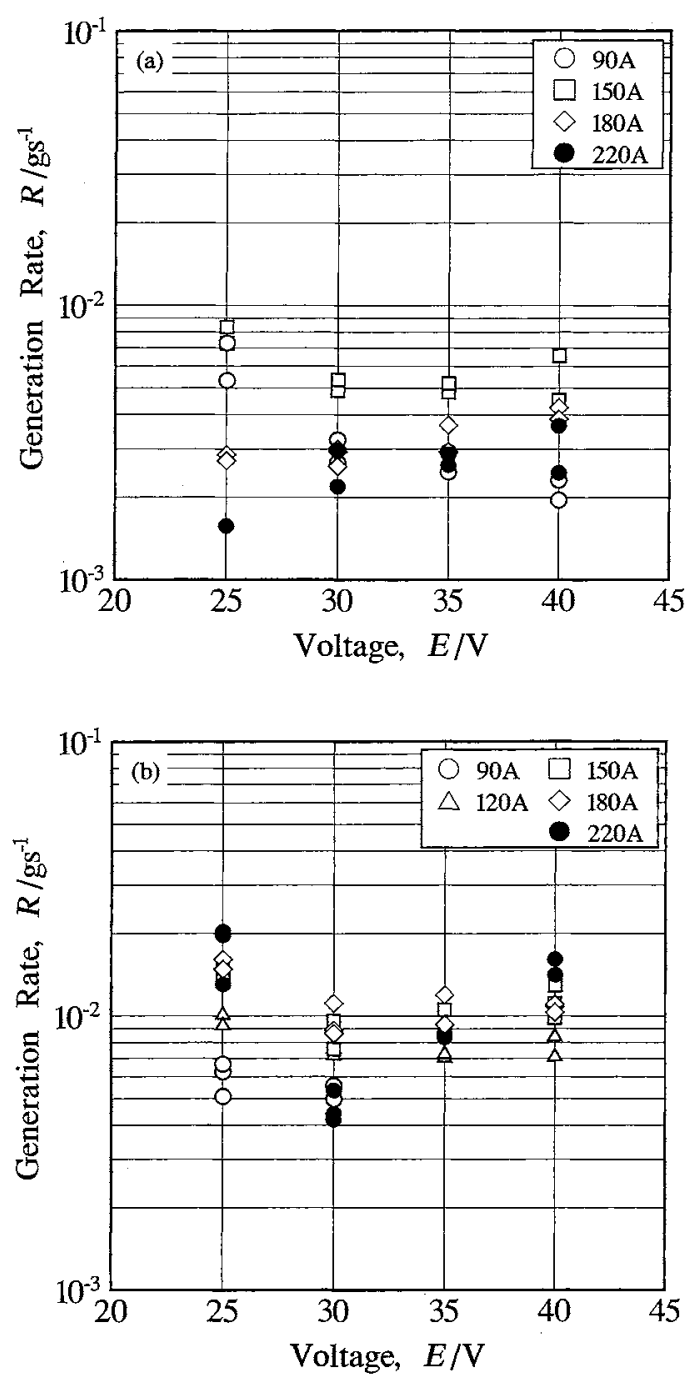

Fig. 4 Relation between arc voltage and generation rate. Hydrogen content is $50 \%$. (a) $\theta=90^{\circ}$, (b) hemisphere.

\section{4. 投入電力の効果}

Figs. 3 特よび 4 は各々電流一定执よび電王一定の条件下 における生成速度の関係でめるが，投入電力量 $(P)$ で生成速 度の値を整理すると Fig. 5 (a) $\left(\theta=90^{\circ}\right)$ 抗よび(b) (半球)に なる。

電力は電流と電生との積であるため, Fig. 5 は Fig. 3 の 測定点を横軸に平行移動させたたりであるが，超微粒子製造 コストを考光るらで必要である。

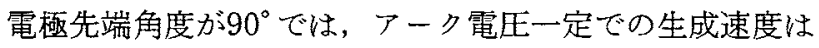
電力の増加に対して最大值を示す傾向にあり，この攧向は各 電圧で同じである. 生成速度の最大值を与える電力はアーク

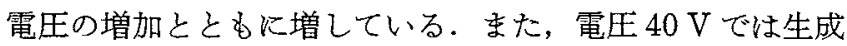
速度が最大值付近で大きくばらついているがとの下限を考慮 すれば, 生成速度の最大值はアーク電王の増加に対して低下 する傾向にある。

電極先端形状が半球の場合では電圧 $40 \mathrm{~V}$, 電力 $8.8 \mathrm{~kW}$ 

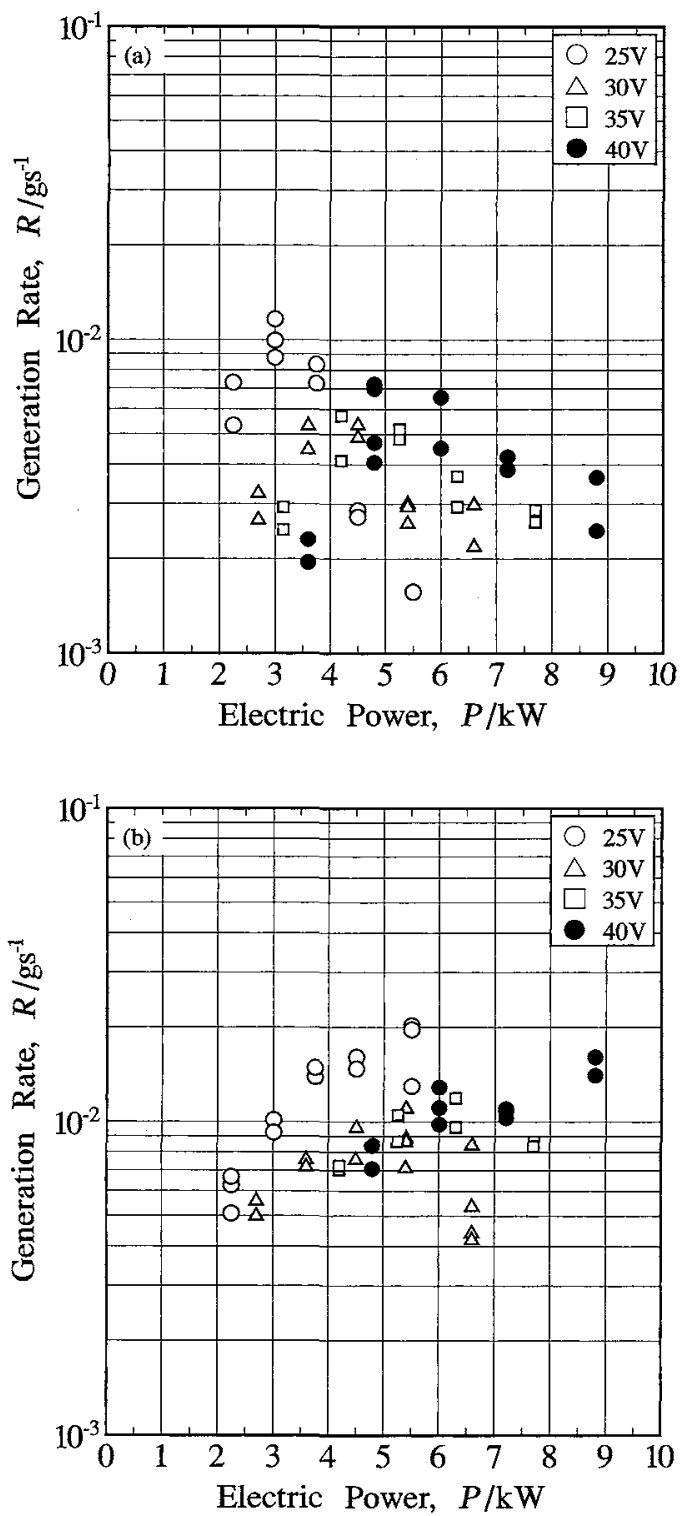

Fig. 5 Relation between electric power and generation rate. (a) $\theta=90^{\circ}$, (b) hemisphere.

での生成速度の値がそれ以下の電力值での値よりる大きいた め明確なことは言党ないが，最大生成速度と電力との関保恃 電王一定であれば電極形状が異なっても傾向としては同様と みなすことができる。

\section{N. 考察}

超微粒子生成機構は過飽和に固溶した水素原子の融液中か らの離脱に伴い金属蒸気が直接的に超微粒子になるとして提 案されている(1)(2)。しかし，アーク直下で発生した金属蒸気

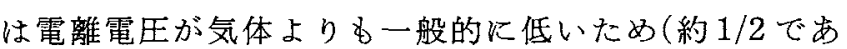
る) (7)，アークプラズマ中では電離状態で存在している可能 性が高い。このため金属蒸気発生 $\rightarrow$ 電離(陽イオン化) $\rightarrow$ 中性 化(超微粒子)の過程学筆者は提案している ${ }^{(3)}$. 超微粒子化の
機構についてさらに検討することは学問的に重要であると考 兄られるが，工業的には超微粒子が高効率で生産できれば良 く，また超微粒子化は蒸気発生が支配的であると考兄られる ため本報ではその機構については論議しない。

\section{1. 生成速度に及ぼす電流の効果}

電流増加比対して超微粒子の生成速度が最大值を持つ現象

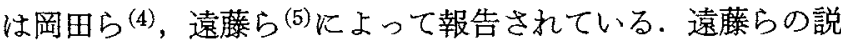
明に上れば，低電流では陽極(試料)からのプラズマ気流 $(8)$ が，大電流では陰極(電極)からのプラズマ気流が強いため結 果として電流の増加に対して生成速度が最大値を示寸ことに なるとしている。しかし，最大値を経た後の最小值の出現㐳 ついては触れていない。この考光方を否定するすのではない が，電流が増加すれば陽極入熱が増す結果としてアーク直下 の陽極温度は上昇するはずであるためこの効果を考虑に入れ る必要がある。

陽極は陰極から発生した電子流によって加熱溶解され，場 合には沸騰状態になる。このような状態ではアーク直下の陽 極表面から金属蒸気が発生することになるが，この蒸発量は 単純には陽極へ入る熱量に依存するため, 電流の増加(陽極 温度の上萛となる)ととも沉蒸気の発生量は增すことになる。

一方, 電流の増加はアーク柱の温度を上昇させるため，ア ーク柱に熱的ピソチ力, 電磁的ピンチ力が作用することとな る。これはアークを収縮させ、アーク柱内の圧力を高める。 この結果として陰極周囲から高速のプラズマ気流(陰極ジ ット流)が陽極へ流れることになる。したがって，圧力の高 い高速の陰極ジェット流が陽極に当たれば蒸気の発生やが抑 制されるものと考克られる。

以上の上う電流の増加炇して二つの過程が考光られ る. 寸なわち, 電流増加炕対して, 陽極温度が上昇して蒸発 量が增す過程と, プラズマ内の圧力増加に起因した陰極ジェ ット流による蒸発量の抑制過程である。この二つの過程は陽 極が溶解している状態では同時仁作用する競合過程と考兄ら れる，低電流では陰極先端での電流密度が低いため発生する 圧力は比較的低く，陰極ジェット流の効果怟低い。このため 電流の増加につれて生成速度が増す傾向となる．この時には 遠藤ら ${ }^{(5)}$ が指摘しているよらに陽極からのジェット流も生成 速度の增加に寄与していると考㝋られる。一方，大電流では 陽極加熱の効果よりも陰極シェット流による蒸気発生抑制効 果が支配的となるため生成速度が低下することになる。この ような過程が競合することによって結果として電流増加に対 して最大の生成速度が生じるものと考穴られる。

以上の考察は生成速度の大小関係が極間仂加る電流の大 小関係のみによって決定され、アーク電圧の影響がないもの として取り扱った。.したがって電圧一定条件で生成速度の電 流传存性を検討した場合には電圧值には依存せず同一である

†蒸気自体の発生の抑制か，あるいは蒸気の電離の抑制のどらら が主であるかは判断できないが雾囲気生力の增加とみれば蒸気 発生そのものの抑制とみなせる。 
と子測される。事塞，Fig. 3 に示したよらに生成速度の電流 依存性はアーク電王にそれ注ど依存せず，電極形状にのみ依 存している．このことは考察の妥当性を示すものであると考 完られる。

\section{2. 生成速度に及ぼす電圧の効果}

上記の考察ではアーク電王の影響には触れていないが， Fig. 4 に示したように電流值一定条件では生成速度のアーク 電死依存性には 3 種類ある。この現象を説明するため, 両 極でのプラズマジェット流速の大小関俰と陽極加熱に基づい て以下のような考察を行った。

先ず小電流で電压が低い(極間間隔が非常に狭い)場合には アーク柱の超高温部分が陽極に接するため陽極物質の蒸発が 著しくなる。また，極間が狭いことは陽極に接するアーク柱 の断面積も小さくなることから陽極電流密度が大となり ${ }^{(9)}$, 陽極ジェット流が增加する．したがって，小電流でからアー ク電王が低い場合には陽極温度の上昇と陽極ジッット流のた わに生成速度が大になる傾向にあると考古られる。この状態 で極間間隔を広げアーク電圧を増すと陽極加熱が低下するこ とになり，生成速度が低下する。この現象が type Iを説明 するものと考学らる。

一方，大電流，低電圧の条件では，陽極加熱就よび陽極シ ェット流が発生するであるらが，除極での電流密度の増加に よる陰極ジェット流が優勢となるため，もしる生成速度が低 くなると考えられる。この状態で極間間隔を広げて電纴を増 すと除極ジット流速が低下するため, 結果として電王増加 とともに生成速度が増すことになる。これが type III説明 するものと考党られる。このように考光ると, type II type I と type 而との中間状態相当する。

電極先端が尖っている場合と半球の場合の結果を比較する と, 半球では type IIIが現れていない。この美異は電極形状 の相違による陰極ジェット流速の大小によって以下のように 定性的淠明される。

\section{3. 生成速度に及ぼす電極角度の効果}

陽極に及ぼすプラズマアーク圧力は電極先端角度の増加と

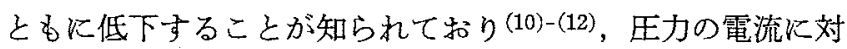
する増加割合は先端角度が小さい注ど大きい(12)，したがっ て，先端角度 $90^{\circ}$ の場合と半球では900の場合のほうがプラ ズマの圧力が大，すなわち陰極ジェット流速が大さいことに なる．電流が低い場合には陰極ジェット流速は電極先端形状 が異なっても小さいため生成速度への影響は低いが，大電流 では先端角度 $90^{\circ}$ でのジェット流速が半球でのそれよりる大 きくなって蒝気発生抑制効果として作用するため, 結果とし
て電極形状が半球の場合に type III゙生じなかったものと考 えることができる，また，電極形状が半球の場合のほらが全 般的に生成速度が高いが，この理由も角度効果を反映したた めであると考完られる。

Fig. 2 に示した結果も角度効果で説明されるが，半球状の 場合の生成速度が先端角度 $135^{\circ}$ でのそれよりも若干低い原 因は，電極形状が必ずしる真の半球でなかったこと，アーク 発生中での電極先端の微妙な損傷などにより生成速度に及ぼ す角度効果が生じたためと思かれる。

\section{V. 結 言}

$\mathrm{Ar}-\mathrm{H}_{2}$ アークプラズマ法を用いて Ni 超微粒子を作成し， この時に超微粒子生成速度に及ぼすーク電厈，電流の効果 について検討した結果をまとめると以下のようになる。

（1）超微粒子生成速度は電王一定条件では電流の増加に対 して最大値を示す。この傾向は電圧值が変化しても同一であ る.

（2）電流一定条件での超微粒子生成速度の電王依存性には 3 種類のタイプがあり，電圧と電流の組合せによりタイプが 異なる。

（3）電極先端の角度効果をる含めた超微粒子生成速度の電 流および電王依存性は両極に発生するジェット流速の大小と 陽極加熱との相互関係によって説明される。

本研究の一部は太陽誘電株式会社の援助を受けたので記し て謝辞とします。

\section{文献}

（1）宇田雅広：日本金属学会会報，22(1983)，412.

(2) 大野 悟, 宇田雅広: 日本金属学会誌, 48(1984), 640 .

（3）斉藤勝男，中山満茂，柴田充蔵：日本金属学会誌， $\mathbf{5 9}(1995)$, 65.

（4）岡田亮二, 茨木善朗, 荒谷 雄, 日置 進: 溶接学会論文集, $3(1985), 68$

（5）遠藤善重, 荒谷 雄, 金丸昌敏, 茨木善朗, 岡田亮二, 日置 進: 粉体工学会誌, 31(1994), 862 .

（6）安藤弘平, 長谷川光雄: 溶接アーク現象, 産業図書( (1962), 97.

(7) J. Emsley: The Elements, 2nd ed, Oxford Univ. Press, (1993).

（8）安藤弘平, 長谷川光雄: 溶接》ーク現象, 産業図畫(㲻), (1962), 169.

(9) O. H. Nestor: J. Appl. Phys., 33(1962), 1638

(10) A. A. Sadek: Dissertation Dr. Eng., Osaka University, (1989), 27.

（11）平岡和雄, 岡田 明, 稲垣道夫：溶接学会論文集, 3(1985), 10.

(12) J.F.ランカスター編：溶接アークの物理, 溶接学会溶接アー ク物理研究委員会, (1980), 243. 